\title{
Ki-67 is a prognostic parameter in breast cancer patients: results of a large population-based cohort of a cancer registry
}

\author{
E. C. Inwald • M. Klinkhammer-Schalke • \\ F. Hofstädter $\cdot$ F. Zeman $\cdot$ M. Koller • \\ M. Gerstenhauer $\cdot$ O. Ortmann
}

Received: 27 March 2013/Accepted: 30 April 2013/Published online: 16 May 2013

(c) The Author(s) 2013. This article is published with open access at Springerlink.com

\begin{abstract}
The proliferation marker Ki-67 is one of the most controversially discussed parameters for treatment decisions in breast cancer patients. The purpose of this study was to evaluate the routine use and value of Ki-67 as a prognostic marker, and to analyze the associations between Ki-67 and common histopathological parameters in the routine clinical setting. Data from the clinical cancer registry Regensburg (Bavaria, Germany) were analyzed. Within the total data pool of 4,692 female patients, who had been diagnosed between 2005 and 2011, in 3,658 cases Ki67 was routinely determined. Thus, a total of 3,658 patients with invasive breast cancer were included in the present study and used for statistical analysis. Ki-67 expression was associated with the common histopathological parameters. The strongest correlation was found between grading and Ki-67 $(P<0.001)$. In terms of survival analyses, Ki-67 was categorized into five categories (reference category Ki-67 $\leq 15 \%$ ) due to a nonlinear relationship to overall survival (OS). In multivariable analysis, Ki-67 was an independent
\end{abstract}

E. C. Inwald $(\bowtie) \cdot$ O. Ortmann

Department of Gynecology and Obstetrics, University of Regensburg, Caritas Krankenhaus St. Josef Regensburg, Landshuter Straße 65, 93053 Regensburg, Germany

e-mail: elisabeth.inwald@klinik.uni-regensburg.de

M. Klinkhammer-Schalke $\cdot$ M. Gerstenhauer

Tumor Center Regensburg e.V., University of Regensburg, Regensburg, Germany

\section{F. Hofstädter}

Institute of Pathology, University of Regensburg, Regensburg, Germany

F. Zeman · M. Koller

Center for Clinical Studies, University Hospital Regensburg,

Regensburg, Germany prognostic parameter both for disease-free survival (DFS) (Ki-67 $>45 \%, \mathrm{HR}=1.96, P=0.001)$ as well as for OS (Ki-67: 26-35\%, HR $=1.71, P=0.017$; Ki-67: 36-45 \%, $\mathrm{HR}=2.05, \quad P=0.011 ; \quad \mathrm{Ki}-67>45 \%, \quad \mathrm{HR}=2.06$, $P=0.002)$ independent of common clinical and histopathological factors. The 5-year DFS (OS) rate was $86.7 \%$ $(89.3 \%)$ in patients with a Ki-67 value $\leq 15 \%$ compared to $75.8 \%(82.8 \%)$ in patients with a Ki-67 value $>45 \%$. Based on the data from a large cohort of a clinical cancer registry, it was demonstrated that $\mathrm{Ki}-67$ is frequently determined in routine clinical work. Ki-67 expression is associated with common histopathological parameters, but is an additional independent prognostic parameter for DFS and OS in breast cancer patients. Future work should focus on standardization of Ki-67 assessment and specification of its role in treatment decisions.

Keywords Ki-67 - Primary breast cancer - Cancer Registry $\cdot$ Prognostic factor · Disease-free survival . Overall survival

\section{Introduction}

Breast cancer is known to be a heterogeneous disease. Different subtypes exist which can be defined either by means of genetic array testing or based on approaches using immunohistochemical analyses [1]. In multigene tests especially, proliferation has a substantial impact on the prediction of the risk of recurrence [2,3]. Likewise, in addition to the conventional histopathological parameters, the assessment of proliferation is one of the major factors for the treatment decisions in breast cancer patients [4]. A wide range of techniques is available to assess tumor cell proliferation such as calculating mitotic figures in stained 
tissue segments, flow cytometric analysis to determine the proportion of cells being in the $\mathrm{S}$ phase of the cell cycle, examination of thymidine-labeling index, proliferating cell nuclear antigen (PCNA), or cyclins E and D [5-7].

$\mathrm{Ki}-67$ is a nuclear protein being associated with cellular proliferation and was originally identified by Gerdes et al. [8] in the early 1980s, using a mouse monoclonal antibody directed against a nuclear antigen from a Hodgkin's lymphoma-descended cell line. The most prevalent analysis method of Ki-67 antigen is the immunohistochemical evaluation. It was shown that $\mathrm{Ki}-67$ nuclear antigen is expressed in certain phases of the cell cycle namely S, G1, $\mathrm{G} 2$, and $\mathrm{M}$ phases, but is nonexisting in $\mathrm{G} 0[9,10]$. In samples from normal breast tissue, it was found that Ki-67 is also expressed at low levels ( $<3 \%$ of cells) in ERnegative cells, but not in ER-positive cells [11]. By means of immunostaining with the monoclonal antibody Ki-67, it is possible to assess the growth fraction of neoplastic cell populations. However, to date no standard operating procedure (SOP) or generally accepted cut-off definition for Ki-67 exists $[12,13]$. For this reason, both the interlaboratory and the interstudy comparability of Ki-67 are limited [14-16]. Therefore, Ki-67 is not implemented in standard routine pathology so far.

Nevertheless, this problem is known and several strategies for improvement have been initiated in Germany such as introduction of quality assurance conferences and pathologists' participation in round robin tests. Regarding the evaluation of $\mathrm{Ki}-67$, the round robin test started in the beginning of 2010 and includes the reproducibility of the $\mathrm{Ki}-67$ index in the context of lymphoma diagnostics.

A meta-analysis involving 12,155 patients demonstrated that the Ki-67 positivity confers a higher risk of recurrence and a worse survival rate in patients with early breast cancer. Even though this meta-analysis could not scrutinize if $\mathrm{Ki}-67$ had independent prognostic value beyond the standard clinico-pathological variables, it confirmed that high levels of Ki-67 are associated with worse prognoses [17]. Another meta-analysis investigating the proliferation markers and survival in early breast cancer included data from 32,825 patients and concluded that Ki-67 was associated with worse survival rates [7]. Nevertheless, it was assumed that this marker is not ready for routine use. The American Society of Clinical Oncology (ASCO) Tumor Marker Guidelines Committee did not advise the use of $\mathrm{Ki}-67$ for prognosis in patients with newly identified breast cancer because of insufficient quality assurance [18]. Recently, the "International Ki-67 in Breast Cancer Working Group" published their recommendations based on current evidence concerning the evaluation and the interpretation of $\mathrm{Ki}-67$, pursuing to increase the interlaboratory comparability and analytical validity of this marker in clinical practice, which is one of the most robust biomarkers measured by immunohistochemistry (IHC). They emphasized the potential of Ki-67 involving prognosis, prediction of relative response or deficiency to chemotherapy, and as a dynamic biomarker of the treatment effectiveness [19]. Furthermore, in the 2011 and in the 2013 St Gallen Consensus Conference, adding Ki-67 was recommended for the determination of proliferation and the differentiation of luminal A and B tumors [14-16] as pioneered by Perou et al. [20], who obtained groundbreaking results with regards to intrinsic molecular breast cancer subtypes. In the 2013 St Gallen Consensus Conference, the majority of panelists voted Ki-67 for taking into account regarding the application of adjuvant chemotherapy in individual cases [16].

However, neither in the St Gallen Conference, nor in the ASCO recommendations $\mathrm{Ki}-67$ was advocated for routine use. Equally, the analysis of Ki-67 is not recommended in the recent update of the German interdisciplinary S3 Guidelines for Diagnosis, Treatment and Follow-up Care of Breast Cancer (Updated version 07/2012, registry number 032-045OL of Association of the Scientific Medical Societies, AWMF). Nevertheless, in routine clinical work, Ki-67 is widely determined in breast cancer tissue and used as an additional factor for decision making on adjuvant treatment strategies.

In the last years, several multigene tests of risk assessment in early breast cancer have been developed including different proliferation-related genes-among others Ki-67-to optimize the treatment and avoid unnecessary chemotherapy. Two large ongoing prospective randomized multicenter studies, called TAILORx (Trial for Assigning IndividuaLized Options for Treatment Rx) [21] using Oncotype DX ${ }^{\circledR}$ [22], and MINDACT (Microarray in NodeNegative Disease May Avoid ChemoTherapy) [23] using Mammaprint ${ }^{\circledR}$ [24] investigate the role of these multigene assays in identifying the benefit of chemotherapy in addition to the endocrine treatment in node-negative early breast cancer [25]. Furthermore, the St Gallen Conference 2011 and 2013 considered IHC as state of the art for clinical routine $[14,16]$.

The aim of this study was to evaluate the routine use and value of $\mathrm{Ki}-67$ as a prognostic marker in breast cancer. Data from a regional population-based cancer registry (Tumor Centre Regensburg, Bavaria, Germany) were analyzed. Associations between Ki-67, clinical and histopathological parameters were evaluated. This study included data from six institutes for pathology including the university hospital and private institutions, and investigated the use of Ki-67 in the routine clinical setting of different certified and noncertified breast cancer centers. 


\section{Patients, materials and methods}

\section{Database}

In this study data from the Tumor Centre Regensburg (Bavaria, Germany) were analyzed, a population-based regional cancer registry covering a population of more than 2.2 million people including Upper Palatinate and Lower Bavaria. The Clinical Cancer Registry Regensburg was founded in 1991, and currently disposes the follow-up of 192,000 patients and 700,000 (695,760 in 2010) electronic sheets of documentation. These sheets contain information about diagnosis, course of disease, therapies, and the whole follow-up. More than 1,000 practicing doctors, the University Hospital Regensburg and 53 regional hospitals of Upper Palatinate and Lower Bavaria are involved in the area-wide, population-based, cross sectorial documentation of cancer. Using this data pool, analyses of the structures of patient-centered care in the region are possible. Pursuant to the German Robert-Koch institute (RKI), the Tumor Centre Regensburg comprises $100 \%$ of the estimated number of cases of tumors. For this reason, the completeness of data is given and publication bias is widely excluded.

The current study considers patients with primary, nonmetastatic (M0), not neo-adjuvant treated invasive breast cancer. The population-based data were routinely analyzed in each case and documented in the cancer registry on the basis of medical reports, pathology, and follow-up records, independently of primary studies' interests. The clinical cancer registry collects the information on recurrence and mortality. Mortality data were obtained real time from all the regional registry offices.

The present data pool contained 4,692 female patients with invasive breast cancer who had been diagnosed between January 2005 and December 2011 (7 years). This period is congruent to the certification of breast centers by the German Cancer Society (DKG) and German Society of Senology (DGS) and to the implementation of pathologists' breast cancer specific quality assurance procedures in the investigated region. Breast cancer was defined according to the ICD-10 classification as C50 (invasive breast cancer). Within the total data pool of 4,692 breast cancer patients, Ki-67 was available in 3,658 cases. Thus, the sample of $n=3,658$ patients was used for all the statistical analyses.

\section{Definitions}

Disease-free survival (DFS) was defined as the period of time from diagnosis to any relapse (including ipsilateral breast recurrence), the appearance of a second breast cancer (including contralateral breast cancer) or to death from any cause. Overall survival (OS) was defined as the length of time from cancer diagnosis until death from any cause.

Quality assurance methods

Consistency among the different pathologists and quality control in this cancer registry area are established due to various internal and external quality assurance methods. Internal quality assurance to ascertain intralaboratory uniformity is warranted by the use of controls of staining intensity with the on-slide positive controls. External quality assurance is established through three measures: first, certification/accreditation of the pathologies according to DIN EN ISO 9001; second, implementation of breast cancer specific quality circles, and third, pathologists' participation in the German interlaboratory trials.

\section{Analysis of Ki-67}

Regarding the analysis of Ki-67, the following methods were used in this cohort:

- Immunohistochemical staining is conducted and the proportion of the malignant cells staining positive for the nuclear antigen Ki-67 is evaluated in a quantitative and visual way using light microscopes.

- Ki-67 values are acquired as the percentage of positively marking malignant cells using the antihuman Ki-67 monoclonal antibody MIB1 which is one of the most commonly used antibodies and considered as the "gold standard" [19].

- The Ki-67 percentage score is defined as the percentage of positively stained tumor cells among the total number of malignant cells assessed [11]. Withal only the positivity is of interest independent of the intensity of coloration. To ensure quality assurance of the staining, positive control tissues are completed.

- A Ki-67 cut-off point of $15 \%$ was defined according to the experience of different pathologists as well as national and international recommendations at present $[1,7,12,15,17]$.

- The complete specimen is investigated and checked for immunostaining tumor cell nuclei. Scoring is conducted considering the whole tumor section and not only limiting to the hot spots of the carcinoma or to the most evident positive parts within the invasive segment or the front of necrosis.

In summary, the Ki-67-labeling index is the percentage of cells with Ki-67-positive nuclear immunostaining. Concerning data selection, Ki-67 values of surgical tumor tissue preparations were taken as these immunohistochemical analyses are decisive for further therapy scheduling. 


\section{Statistics}

Continuous data are expressed as mean \pm standard deviation (SD) and categorical data as frequency counts (percentages). Baseline characteristics of patients were compared among Ki-67 quartiles by analysis of variance (ANOVA) for continuous variables, and by Chi squared tests for categorical variables. Ki-67 mean values were compared by ANOVA for each categorical baseline variable. Univariable analyses by the use of the Cox-proportional hazards regression model were performed to assess the influence of Ki-67 and of established clinical and histopathological parameters on the endpoints (DFS and OS). To determine the impact of Ki-67 on DFS and OS independently of all other risk factors, a multivariable adjusted Cox-proportional hazards model was used. Since the parameter Ki-67 violated the linearity assumptions of the Cox model, we performed an exploratory graphical analysis of the nonlinear relationship of Ki-67 to mortality by the use of restricted cubic splines (RCS) with five knots in a multivariable Cox-regression analysis. For simplicity, the knots were designated at the 5th, 25th, 50th, 75th, and 95th percentiles. The results were adjusted for the same covariates as in the main Cox-regression analysis. According to the spline analysis and due to the non-normal distribution characterized by a few Ki-67 values with a very high-frequency count, the $\mathrm{Ki}-67$ values were categorized into five categories $[\leq 15 \%$ (minimum to median), $16-25 \%$ (median to p75), 26-35, 36-45, >45\%] for survival analyses. Since no imputation methods for missing values were used, the multivariable model contains only patients with full data sets according to the predictive variables. A two-sided $P$ value of $<0.05$ was considered to indicate the statistical significance. Hazard ratios (HR) and corresponding $95 \%$ confidence intervals (CI) were calculated and considered as statistically significant if CI excluded 1.0. All analyses were performed using IBM SPSS Statistics 20.0, R (version 2.14.2) using the package survival and SAS 9.3 (Institute, Cary, NC, USA).

\section{Results}

Distribution of Ki-67 across different pathologies

To assess the interlaboratory consistence, we investigated both the distribution of patients in different pathologies and the distribution of Ki-67 across different pathologies. A total of six pathological institutions was involved in Ki-67 diagnostics, and four of them diagnosed the vast majority of patients, $n=3,374 / 3,658$ (92.2 \%). Due to the small number of patients in pathology number $5(n=79)$ and pathology number $6(n=61)$, these patients and the patients who could not be assigned to any pathology $(n=144)$ were merged into a separate category, pathology number $9(n=285)$, as shown in Fig. 1. The distribution of Ki-67 across the different pathologies displayed to be very homogenous, which can be referred to the effectiveness of the above mentioned quality assurance methods.

\section{Patients' characteristics}

The total data pool (2005-2011) consists of 4,692 patients with invasive breast cancer. The average number of primary breast cancer patients was 670 per year (Range: 546-768). Ki-67 was available in $78 \%$ (3,658 patients). In $22 \%$ (1,034 patients), Ki-67 values were missing due to the absent information of $\mathrm{Ki}-67$ in the medical reports or no determination. For representative causes, only these patients with a present $\mathrm{Ki}-67$ value were included in the further statistics. Thus, a total of 3,658 patients were eligible for this retrospective population-based analysis. Of these, 805 patients $(22.0 \%)$ were premenopausal and 2,853 $(78.0 \%)$ were postmenopausal. The mean age was 62 years (median: 63 years; range: $24-99$ years). Detailed information on patients' and pathological characteristics are given in Table 1 . The use of quartiles in Table $1(<10,10-14$, $15-24, \geq 25 \%$ ) was based on the St Gallen recommendations to set a cut-off between minor/major $14 \%[14,15]$.

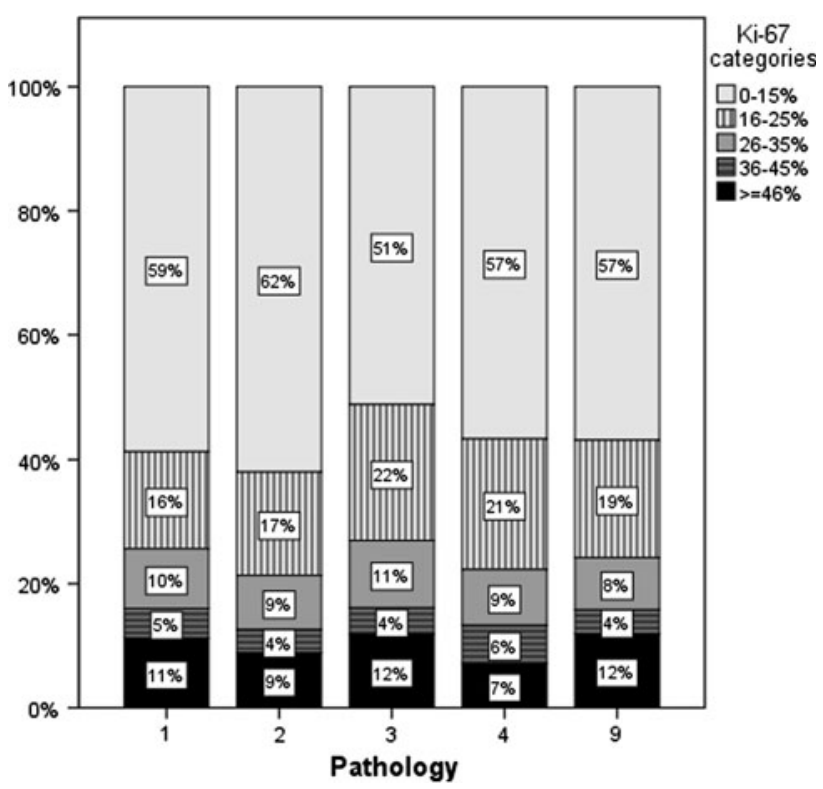

Fig. 1 Distribution of patients and distribution of Ki-67 categories across different pathologies. Due to the small number of patients in pathology number $5(n=79)$ and pathology number $6(n=61)$, these patients and the patients who could not be assigned to any pathology $(n=144)$ were subsumed under pathology number 9 $(n=285)$, as shown in Fig. 1 
Table 1 Associations between Ki-67 quartiles and the clinical and histopathological parameters

\begin{tabular}{|c|c|c|c|c|c|c|}
\hline Characteristic & $\begin{array}{l}\text { Ki-67 (\%) 1st } \\
\text { quartile }<10 \%\end{array}$ & $\begin{array}{l}\text { Ki-67 (\%) 2nd } \\
\text { quartile } 10-14 \%\end{array}$ & $\begin{array}{l}\text { Ki-67 (\%) 3rd } \\
\text { quartile } 15-24 \%\end{array}$ & $\begin{array}{l}\text { Ki-67 (\%) 4th } \\
\text { quartile } \geq 25 \%\end{array}$ & Total $n(\%)$ & $P$ value $^{\mathrm{a}}$ \\
\hline Age (Mean \pm SD) & $63.9 \pm 12.5$ & $63.0 \pm 13.1$ & $62.7 \pm 13.2$ & $60.3 \pm 14.7$ & $62.4 \pm 13.5$ & $<0.001$ \\
\hline \multicolumn{7}{|l|}{ Menopausal status } \\
\hline Premenopausal & $131(16.1 \%)$ & $173(20.4 \%)$ & $216(22.6 \%)$ & $285(27.4 \%)$ & $805(22.0 \%)$ & \multirow[t]{2}{*}{$<0.001$} \\
\hline Postmenopausal & $683(83.9 \%)$ & $675(79.6 \%)$ & $739(77.4 \%)$ & $756(72.6 \%)$ & $2,853(78.0 \%)$ & \\
\hline \multicolumn{7}{|l|}{ Tumor size } \\
\hline pT1 & $522(66.3 \%)$ & $499(61.0 \%)$ & $497(54.1 \%)$ & $437(43.8 \%)$ & $1,955(55.5 \%)$ & \multirow[t]{4}{*}{$<0.001$} \\
\hline pT2 & $209(26.6 \%)$ & $265(32.4 \%)$ & $337(36.7 \%)$ & $472(47.3 \%)$ & $1,283(36.4 \%)$ & \\
\hline pT3 & $26(3.3 \%)$ & $24(2.9 \%)$ & $41(4.5 \%)$ & $42(4.2 \%)$ & $133(3.8 \%)$ & \\
\hline pT4 & $30(3.8 \%)$ & $30(3.7 \%)$ & $43(4.7 \%)$ & $46(4.6 \%)$ & $149(4.2 \%)$ & \\
\hline \multicolumn{7}{|l|}{ Nodal status } \\
\hline N0 & $549(71.4 \%)$ & $542(57.7 \%)$ & $524(58.0 \%)$ & $531(54.8 \%)$ & $2,146(62.3 \%)$ & \multirow[t]{4}{*}{$<0.001$} \\
\hline N1 & $160(20.8 \%)$ & $176(22.0 \%)$ & $223(24.7 \%)$ & $252(26.0 \%)$ & $811(23.6 \%)$ & \\
\hline $\mathrm{N} 2$ & $37(4.8 \%)$ & $49(6.1 \%)$ & $89(9.9 \%)$ & $102(10.5 \%)$ & $277(8.0 \%)$ & \\
\hline N3 & $23(3.0 \%)$ & $34(4.2 \%)$ & $67(7.4 \%)$ & $84(8.7 \%)$ & $208(6.0 \%)$ & \\
\hline \multicolumn{7}{|l|}{ Histology } \\
\hline Ductal & $594(73.0 \%)$ & $644(75.9 \%)$ & $811(84.9 \%)$ & $964(92.6 \%)$ & $3,013(82.4 \%)$ & \multirow[t]{3}{*}{$<0.001$} \\
\hline Lobular & $122(15.0 \%)$ & $142(16.7 \%)$ & $121(12.7 \%)$ & $41(3.9 \%)$ & $426(11.6 \%)$ & \\
\hline Other & $98(12.0 \%)$ & $62(7.3 \%)$ & $23(2.4 \%)$ & $36(3.5 \%)$ & $219(6.0 \%)$ & \\
\hline \multicolumn{7}{|l|}{ Grading } \\
\hline G1 & $309(38.1 \%)$ & $224(26.5 \%)$ & $103(10.8 \%)$ & $28(2.7 \%)$ & $664(18.2 \%)$ & \multirow[t]{3}{*}{$<0.001$} \\
\hline G2 & $469(57.9 \%)$ & $556(65.8 \%)$ & $676(71.0 \%)$ & $363(35.1 \%)$ & $2,064(56.7 \%)$ & \\
\hline G3 & $32(4.0 \%)$ & $65(7.7 \%)$ & $173(18.2 \%)$ & $643(62.2 \%)$ & $913(25.1 \%)$ & \\
\hline \multicolumn{7}{|l|}{ Lymphatic invasion } \\
\hline L0 & $586(77.9 \%)$ & $570(72.4 \%)$ & $542(61.4 \%)$ & $504(52.5 \%)$ & $2,202(65.1 \%)$ & \multirow[t]{2}{*}{$<0.001$} \\
\hline $\mathrm{L} 1$ & $166(22.1 \%)$ & $217(27.6 \%)$ & $341(38.6 \%)$ & $456(47.5 \%)$ & $1,180(34.9 \%)$ & \\
\hline \multicolumn{7}{|l|}{ Vascular invasion } \\
\hline V0 & $726(97.3 \%)$ & $748(96.0 \%)$ & $796(93.0 \%)$ & $841(89.5 \%)$ & $3,111(93.7 \%)$ & \multirow[t]{2}{*}{$<0.001$} \\
\hline V1 & $20(2.7 \%)$ & $31(4.0 \%)$ & $60(7.0 \%)$ & $99(10.5 \%)$ & $210(6.3 \%)$ & \\
\hline \multicolumn{7}{|l|}{ Estrogen receptor } \\
\hline Positive & $790(97.2 \%)$ & $814(96.0 \%)$ & $885(92.8 \%)$ & $648(62.3 \%)$ & $3,137(85.8 \%)$ & \multirow[t]{2}{*}{$<0.001$} \\
\hline Negative & $23(2.8 \%)$ & $34(4.0 \%)$ & $69(7.2 \%)$ & $392(37.7 \%)$ & $518(14.2 \%)$ & \\
\hline \multicolumn{7}{|l|}{ Progesterone receptor } \\
\hline Positive & $702(86.3 \%)$ & $761(89.7 \%)$ & $810(84.9 \%)$ & $550(52.9 \%)$ & $2,823(77.2 \%)$ & \multirow[t]{2}{*}{$<0.001$} \\
\hline Negative & $111(13.7 \%)$ & $87(10.3 \%)$ & $144(15.1 \%)$ & $490(47.1 \%)$ & $832(22.8 \%)$ & \\
\hline \multicolumn{7}{|l|}{ HER2/neu } \\
\hline Positive & $69(8.6 \%)$ & $91(10.9 \%)$ & $168(17.7 \%)$ & $329(31.9 \%)$ & $657(18.2 \%)$ & \multirow[t]{2}{*}{$<0.001$} \\
\hline Negative & $737(91.4 \%)$ & $744(89.1 \%)$ & $779(82.3 \%)$ & $701(68.1 \%)$ & $2,961(81.8 \%)$ & \\
\hline \multicolumn{7}{|l|}{ Receptor status } \\
\hline $\mathrm{ER}+\mathrm{PR}+$ & $698(85.9 \%)$ & $757(89.3 \%)$ & $807(84.6 \%)$ & $525(50.5 \%)$ & $2,787(76.3 \%)$ & \multirow[t]{4}{*}{$<0.001$} \\
\hline $\mathrm{ER}+\mathrm{PR}-$ & $92(11.3 \%)$ & $57(6.7 \%)$ & $78(8.2 \%)$ & $123(11.8 \%)$ & $350(9.6 \%)$ & \\
\hline $\mathrm{ER}-\mathrm{PR}+$ & $4(0.5 \%)$ & $4(0.5 \%)$ & $2(0.2 \%)$ & $21(2.0 \%)$ & $31(0.8 \%)$ & \\
\hline $\mathrm{ER}-\mathrm{PR}-$ & $19(2.3 \%)$ & $30(3.5 \%)$ & $67(7.0 \%)$ & $371(35.7 \%)$ & $487(13.3 \%)$ & \\
\hline
\end{tabular}

${ }^{a} P$ value for Pearson's Chi squared test [except for age (ANOVA)] 
Ki-67 quartiles and histopathological parameters

The mean Ki-67-labeling index for all the patients was $20 \%$ (Mean \pm SD $20.3 \pm 18.1$ ), the median of Ki-67 expression level was $15 \%$ (range: 0-99\%). Premenopausal patients were prone to higher $\mathrm{Ki}-67$ values, while postmenopausal patients were prone to lower Ki-67 percentages. Overall, the majority of tumor tissues $(57 \%)$ showed Ki-67 percentages $\leq 15 \%$. Regarding the tumor size, low-pT stages were associated with low expression of Ki-67. The majority of patients had pT1 $(55.5 \%)$ or pT2 $(36.4 \%)$ tumors, respectively. In these groups, the first and the second Ki-67 quartiles were prevalent. In higher Ki-67 quartiles, the number of patients with more advanced tumor stages was increased. Because of the low numbers of pT3 (133 patients) and pT4 (149 patients) tumors, it is difficult to make conclusions on the differences in the relation between $\mathrm{Ki}-67$ and tumor size. Concerning the nodal status, it was shown that in nodenegative tumors the first Ki-67 quartile was dominant $(71.4 \%)$. In node positive tumors, the percentages of lowKi-67 quartiles was decreasing - in other words higher nodal status was associated with higher Ki-67 quartiles. The evaluation of histological type showed a tendency of ductal type in higher Ki-67 quartiles. The clearest associations between Ki-67 and histopathological parameters were seen in relation to grading. In low-grade tumors (G1), the first and the second Ki-67 quartiles were predominant. The quota of high-Ki-67 percentages in G1 tumors was negligibly small $(2.7 \%)$. Conversely, high-grade tumors were associated with high-Ki-67 quartiles. Only $4.0 \%$ of G3 tumors were found in the first quartile in contrast to $62.2 \%$ in the fourth quartile. Tumors with lymphatic and vascular invasion were inclined to higher proliferation similar to nodal status. Estrogen receptor (ER) positive tumors were associated with low-Ki-67 quartiles. In the first quartile, $97.2 \%$ were ER positive, in the third quartile $92.8 \%$, and in the fourth quartile only $62.3 \%$, respectively. Regarding progesterone receptor (PR), this effect was less distinct. In terms of HER2/ neu, high-Ki-67 quartiles were found in tumors with HER2/ neu overexpression. Absence of HER2/neu overexpression was correlated with low Ki-67 values.

\section{Absolute Ki-67 values and histopathological parameters}

In addition to the analysis of Ki-67 quartiles, absolute Ki67 values and their relation to the histopathologic parameters were examined using ANOVA, as shown in Table 2. Mean Ki-67 in premenopausal patients was 24 and $19 \%$ in postmenopausal patients, respectively. Regarding the tumor size, there were no substantial differences in Ki-67 distribution. Concerning the nodal status, differences of Ki67 values were more distinct. Mean Ki-67 in node-negative tumors was $19 \%$ whereas in N3 tumors it was $24 \%$. Interestingly, in terms of histology, invasive ductal carcinoma had a Ki-67 expression of $22 \%$ in contrast to the lobular tumors which had a mean Ki-67 of $13 \%$. Once again, the differentiation of tumors showed obvious correlation with $\mathrm{Ki}-67$. G1 tumors had $\mathrm{Ki}-67-1 a b e l i n g$ indices of $10 \%, \mathrm{G} 2$ tumors of $16 \%$, and G3 tumors of $37 \%$. Lymphatic and vascular invasion were concordant in their characteristics in relation to $\mathrm{Ki}-67$. Mean $\mathrm{Ki}-67$ of L0 tumors was 18 and $20 \%$ in V0 tumors, whereas in L1 tumors mean Ki-67 was 24 and $28 \%$ in V1 tumors. Somewhat different to Ki-67 quartiles, ER and PR behave similarly in analysis of absolute Ki-67 values with a mean of Ki-67 of $17 \%$ both in ER positive and in PR positive tumors. In receptor negative tumors, Ki-67 expression was higher with $42 \%$ in ER negative and $34 \%$ in PR-negative tumors. Mean Ki-67 of HER2/neu positive tumors was $27 \%$, and $19 \%$ in HER2/neu negative tumors. Consequently, Ki-67 showed an association with all the tested factors in the Pearson's Chi squared test as well as in ANOVA $(P<0.001)$.

Prognostic value of Ki-67 and histopathological parameters in univariable survival analysis

At a median follow-up time of 42 months, 347 deaths were recorded of which 188 were certainly breast cancer-related. According to the RCS analysis (Fig. 2), Ki-67 was found to be nonlinear related to OS between 0 and $15 \%(n=2,074$ patients). Thus, we left the St Gallen based cut-off used in Table 1, and Ki-67 values were categorized into five categories (Ki-67 $\leq 15 \%$ (minimum to median), Ki-67: 16-25\% (median to p75), Ki-67: 26-35, Ki-67: 36-45, Ki$67>45 \%)$ for the survival analyses. Regarding Ki-67, statistically significant effects for DFS and for OS were found in the univariable analysis (Table 3). Figures 3 and 4 present the corresponding Kaplan-Meier survival curves of DFS and OS categorized by Ki-67 of 3,658 patients. All clinical and histopathological parameters (age, menopausal status, tumor size, nodal status, histological type, grading, lymphatic invasion, vascular invasion, ER, PR, and HER2/ neu) were also investigated for their prognostic value in univariable analyses for DFS and OS. All parameters except histological subtype and HER2/-neu overexpression had statistically significant prognostic effects on both DFS and OS. Regarding the HER2/-neu status, a significant $P$ value was only seen for DFS. These results are shown in Table 3 .

Prognostic value of Ki-67 and histopathological parameters in multivariable survival analysis

In the multivariable model with $n=3,174$ complete data sets, Ki-67 remained an independent parameter with respect 
Table 2 Differentiation of continuous Ki-67 percentages by analysis of variance (ANOVA)

\begin{tabular}{|c|c|c|c|}
\hline Characteristic & $\begin{array}{l}\text { Absolute Ki-67 } \\
\text { mean }( \pm S D)\end{array}$ & Total $n$ & $P$ value \\
\hline \multicolumn{4}{|l|}{ Menopausal status } \\
\hline Premenopausal & $24.1( \pm 20.4)$ & 805 & \multirow[t]{2}{*}{$<0.001$} \\
\hline Postmenopausal & $19.3( \pm 17.3)$ & 2,853 & \\
\hline \multicolumn{4}{|l|}{ Tumor size } \\
\hline pT1 & $17.7( \pm 16.3)$ & 1,955 & \multirow[t]{4}{*}{$<0.001$} \\
\hline pT2 & $24.1( \pm 20.3)$ & 1,283 & \\
\hline pT3 & $20.7( \pm 15.7)$ & 133 & \\
\hline pT4 & $20.1( \pm 16.6)$ & 149 & \\
\hline \multicolumn{4}{|l|}{ Nodal status } \\
\hline No & $18.9( \pm 17.9)$ & 2,146 & \multirow[t]{4}{*}{$<0.001$} \\
\hline N1 & $21.6( \pm 18.6)$ & 811 & \\
\hline $\mathrm{N} 2$ & $23.4( \pm 17.9)$ & 277 & \\
\hline N3 & $24.4( \pm 17.0)$ & 208 & \\
\hline \multicolumn{4}{|l|}{ Histology } \\
\hline Ductal & $21.8( \pm 18.7)$ & 3,013 & \multirow[t]{3}{*}{$<0.001$} \\
\hline Lobular & $13.3( \pm 10.7)$ & 426 & \\
\hline Other & $14.5( \pm 17.5)$ & 219 & \\
\hline \multicolumn{4}{|l|}{ Grading } \\
\hline G1 & $9.7( \pm 8.2)$ & 664 & \multirow[t]{3}{*}{$<0.001$} \\
\hline $\mathrm{G} 2$ & $16.2( \pm 12.7)$ & 2,064 & \\
\hline G3 & $37.4( \pm 22.1)$ & 913 & \\
\hline \multicolumn{4}{|c|}{ Lymphatic invasion } \\
\hline L0 & $18.2( \pm 17.3)$ & 2,202 & \multirow[t]{2}{*}{$<0.001$} \\
\hline L1 & $24.3( \pm 18.9)$ & 1,180 & \\
\hline \multicolumn{4}{|l|}{ Vascular invasion } \\
\hline V0 & $19.7( \pm 17.9)$ & 3,111 & \multirow[t]{2}{*}{$<0.001$} \\
\hline $\mathrm{V} 1$ & $27.8( \pm 19.9)$ & 210 & \\
\hline \multicolumn{4}{|l|}{ Estrogen receptor } \\
\hline Positive & $16.8( \pm 14.1)$ & 3,137 & \multirow[t]{2}{*}{$<0.001$} \\
\hline Negative & $41.9( \pm 24.0)$ & 518 & \\
\hline \multicolumn{4}{|c|}{ Progesterone receptor } \\
\hline Positive & $16.5( \pm 13.8)$ & 2,823 & \multirow[t]{2}{*}{$<0.001$} \\
\hline Negative & $33.5( \pm 24.1)$ & 832 & \\
\hline \multicolumn{4}{|l|}{ HER2/neu } \\
\hline Positive & $27.5( \pm 19.0)$ & 657 & \multirow[t]{2}{*}{$<0.001$} \\
\hline Negative & $18.7( \pm 17.5)$ & 2,961 & \\
\hline \multicolumn{4}{|l|}{ Receptor status } \\
\hline $\mathrm{ER}+\mathrm{PR}+$ & $16.1( \pm 13.2)$ & 2,787 & \multirow[t]{4}{*}{$<0.001$} \\
\hline $\mathrm{ER}+\mathrm{PR}-$ & $21.9( \pm 19.1)$ & 350 & \\
\hline $\mathrm{ER}-\mathrm{PR}+$ & $40.6( \pm 27.4)$ & 31 & \\
\hline $\mathrm{ER}-\mathrm{PR}-$ & $41.9( \pm 23.8)$ & 487 & \\
\hline
\end{tabular}

${ }^{a} P$ value for ANOVA

to DFS and OS independent of the common histopathological parameters, as shown in Table 4. Ki-67 (reference Ki-67: 0-15 \%; Ki-67: 16-25 \%, HR $=1.14, P=0.49$; Ki-67: 26-35 \%, HR $=1.71, P=0.017$; Ki-67: 36-45 \%, $\mathrm{HR}=2.05, P=0.011 ; \mathrm{Ki}-67>45 \%, \mathrm{HR}=2.06, P=$
0.002), age, tumor size, nodal status, ER, and HER2/neu were all independent unfavorable factors in OS. In the analysis of DFS, Ki-67 (Ki-67: 16-25\%, HR $=1.00$, $P=1.00$; Ki-67: 26-35 \%, HR $=1.44, P=0.07$; Ki-67: $36-45 \%, \mathrm{HR}=1.50, P=0.11 ; \mathrm{Ki}-67>45 \%$, HR $=$ $1.96, P=0.001)$, age, menopausal status, tumor size, nodal status, grading, and vascular invasion were all independent unfavorable prognostic parameters.

The 3- and 5-year DFS and OS rates according to Kaplan-Meier analyses, each categorized by Ki-67, are shown in Table 5.

\section{Discussion}

To our knowledge, this is one of the largest retrospective studies analyzing the data from a high-quality clinical cancer registry on routine use and prognostic significance of Ki-67 in breast cancer patients. Our study was performed using the data of a clinical cancer registry which reflects the routine care in different institutions. First of all, it was found that $\mathrm{Ki}-67$ is determined in a large proportion of tumors from patients with primary breast cancer. This suggests that the parameter is used in clinical routine although not recommended in national guidelines. The study demonstrated that the Ki-67 showed an association with the common histopathologic parameters. The effect was clearly seen in the association between $\mathrm{Ki}-67$ and grading. This result reinforces the assumption of a similar behavior of these two parameters, both associated with proliferation. Similarly higher tumor stages and higher nodal status were associated with higher $\mathrm{Ki}-67$ quartiles indicating that the more aggressive the tumor is the higher is the percentage of cells positively stained for Ki-67. Notably, in multivariable analysis, Ki-67 was a self-reliant parameter in respect of DFS and OS. Patients with tumors that had a high-Ki-67-labeling index (Ki-67 > $25 \%)$ had both worse DFS and OS than patients with tumors that had low-Ki-67-labeling index (Ki-67 $<25 \%)$. Furthermore, it was found that $\mathrm{Ki}-67$ values between 0 and $15 \%$ are not linearly related to DFS and OS, while Ki-67 values $>15 \%$ seem to have a linear relationship. Consequently, this study confirms that high-Ki-67-labeling index is a prognostic parameter for DFS as well as for OS. As to Ki-67 categories, the $P$-values of all the three categories in the fourth quartile (Ki-67: 26-35, 36-45 and >45 \%) were statistically significant, compared to the first category [Ki-67 $\leq 15 \%$ (median)] which raises the question of an optimal Ki-67 cut-off point. This should be a subject of further research. Even though the gene expression profiling is already commercially available to analyze tumor characteristics, currently this method is not likely to be widely adopted in clinical routine work because of high cost and 


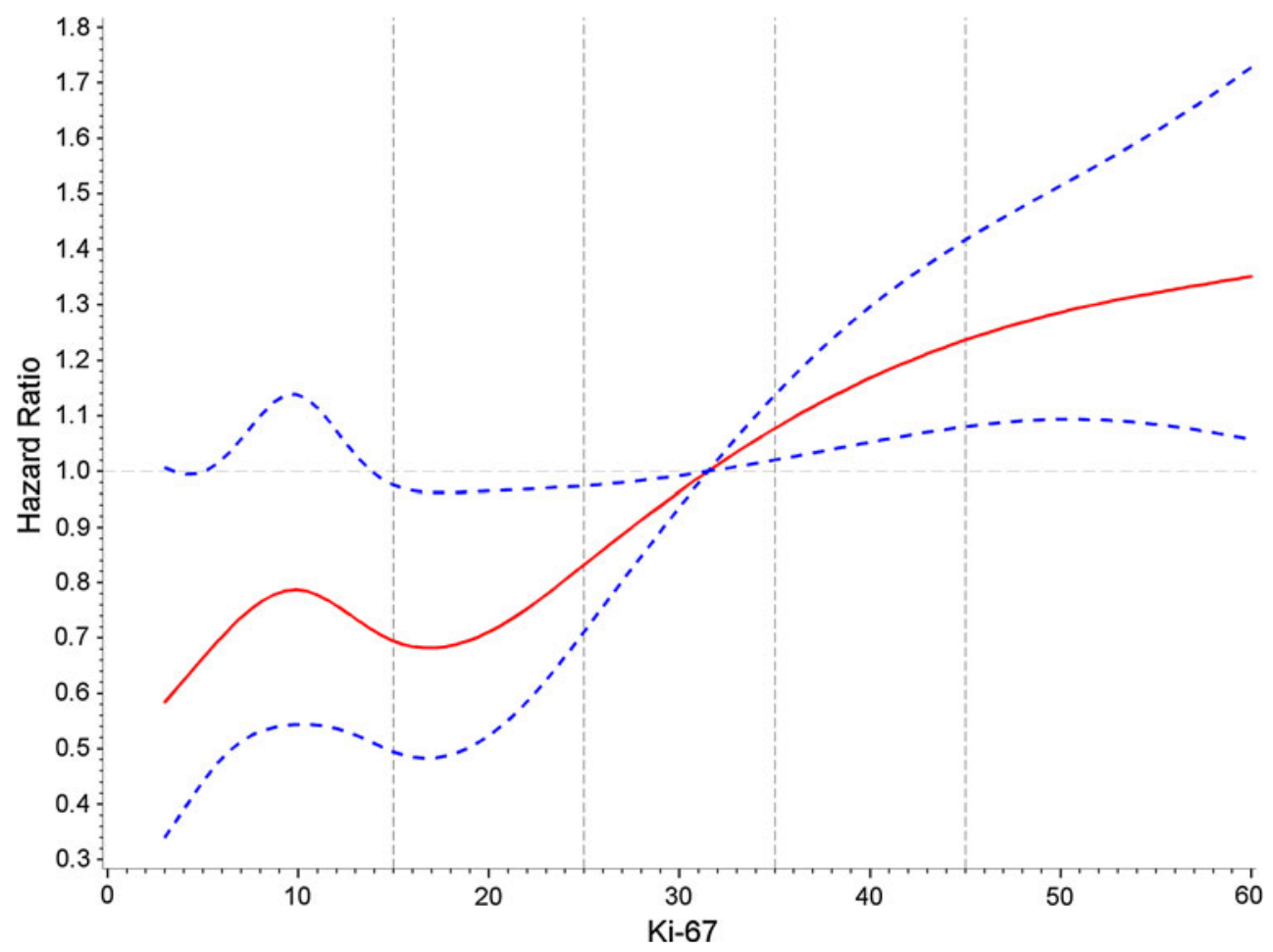

Fig. 2 Adjusted hazard ratio for mortality according to Ki-67. Ki-67 was added to a multivariable Cox-regression model using restricted cubic splines (Knots at the 5th, 25th, 50th, 75th and 95th percentiles). We adjusted for age, menopausal status, tumor size, nodal status, histology, tumor grading, lymphatic invasion, vascular invasion,

lack of evidence from prospective trials. Previous studies were able to demonstrate that a prognostic model, the IHC 4 score, using ER, PR, HER2, and Ki-67 provides similar prognostic information to that in the 21-gene Genomic Health recurrence score [26]. Therefore, the use of Ki-67 and its correlation with the routine clinical and histopathological parameters were evaluated in a large data set. Currently, neither in the St Gallen nor in the ASCO recommendations nor in the German interdisciplinary S3 Guidelines for the Diagnosis, Treatment and Follow-up of Breast Cancer Ki-67 has been introduced as a routine parameter. However, our data showed that Ki-67 is used to a considerable extent in routine clinical work. In contrast to Ki-67, histological grading has been one of the most commonly used parameters for therapy decision-making for a long time. Grading describes differentiation as well as proliferation in various tumors. The most relevant problem using this factor is reproducibility among different institutions [27]. Elston and Ellis therefore modified the Bloom and Richardson grading system and designed the Nottingham combined histologic grade [28]. Their classification system was an important landmark in terms of achieving reproducibility of grading assessments [29]. Among classical histopathological parameters, grading was strongly correlated to Ki-67-labeling indices. This correlation was estrogen receptor, progesterone receptor, and HER2/neu. The solid line represents the hazard ratio estimation and the dotted lines represent the $95 \%$ confidence band. The vertical reference lines represent the $\mathrm{Ki}-67$ categories used for the latter cox-regression models

proven in various former studies [30-36]. These findings are in accordance to our results. A further powerful correlation was noted in steroid receptor status and Ki-67 corresponding with previous studies. ER status has been largely identified as being inversely correlated with Ki-67, with the higher rates of ER positivity shown in the lowest proliferating tumors [35, 37-40]. Moreover, it could be demonstrated that high levels of Ki-67 are associated with HER2/-neu positivity according to former studies [41]. Viale et al. [42] concluded that higher values of Ki-67labeling index were associated with adverse prognostic factors. In their univariate analyses, high $(>11 \%)$ Ki-67labeling index was associated with larger tumors, higher tumor grade, peritumoral vascular invasion, and HER-2 positivity (each $P<0.01$ ). Vascular and lymphatic invasion were also associated with higher $\mathrm{Ki}-67$ values as previously described by Jacquemier et al. [43]. Consequently, one of the major findings of this study was that Ki-67 was associated with all the commonly used histopathologic parameters confirming the results of similar studies regarding clinical work [44]. One of the main questions was whether $\mathrm{Ki}-67$ provides prognostic information in routine use. In former studies, Ki-67 has also been valued as a prognostic factor being associated with breast cancer outcomes [3, 30, 36, 45-49]. Ki-67 
Table 3 Association of Ki-67 with clinical and histopathological parameters in univariable analysis

\begin{tabular}{|c|c|c|c|c|c|c|}
\hline \multirow[t]{2}{*}{ Characteristic } & \multicolumn{3}{|c|}{ Disease-free survival } & \multicolumn{3}{|c|}{ Overall survival } \\
\hline & HR & $95 \% \mathrm{CI}$ & $P \leq$ & HR & $95 \% \mathrm{CI}$ & $P \leq$ \\
\hline Age $(n=3,658)$ & 1.05 & $1.05-1.06$ & 0.001 & 1.07 & $1.06-1.08$ & 0.001 \\
\hline \multicolumn{7}{|c|}{ Ki-67-categories $(\%)(n=3,658)$} \\
\hline$\leq 15$ & 1 & & & 1 & & \\
\hline $16-25$ & 1.24 & $0.95-1.61$ & 0.11 & 1.26 & $0.94-1.69$ & 0.12 \\
\hline $26-35$ & 2.02 & $1.52-2.69$ & 0.001 & 2.12 & $1.55-2.90$ & 0.001 \\
\hline $36-45$ & 2.00 & $1.34-2.98$ & 0.001 & 2.12 & $1.37-3.26$ & 0.001 \\
\hline$>45$ & 2.42 & $1.87-3.15$ & 0.001 & 2.13 & $1.58-2.88$ & 0.001 \\
\hline \multicolumn{7}{|c|}{ Menopausal status $(n=3,658)$} \\
\hline Premenopausal & 1 & & & 1 & & \\
\hline Postmenopausal & 2.19 & $1.64-2.93$ & 0.001 & 3.20 & $2.20-4.66$ & 0.001 \\
\hline \multicolumn{7}{|c|}{ Tumor size $(n=3,520)$} \\
\hline pT1 & 1 & & & 1 & & \\
\hline pT2 & 2.99 & $2.35-3.80$ & 0.001 & 3.08 & $2.33-4.05$ & 0.001 \\
\hline pT3 & 5.80 & $3.92-8.59$ & 0.001 & 5.77 & $3.70-9.02$ & 0.001 \\
\hline pT4 & 7.68 & $5.46-10.80$ & 0.001 & 9.44 & $6.52-13.66$ & 0.001 \\
\hline \multicolumn{7}{|c|}{ Nodal status $(n=3,442)$} \\
\hline N0 & 1 & & & 1 & & \\
\hline N1 & 2.20 & $1.71-2.83$ & 0.001 & 2.01 & $1.51-2.69$ & 0.001 \\
\hline N2 & 3.23 & $2.34-4.46$ & 0.001 & 2.92 & $2.02-4.23$ & 0.001 \\
\hline $\mathrm{N} 3$ & 4.39 & $3.19-6.05$ & 0.001 & 4.05 & $2.82-5.83$ & 0.001 \\
\hline \multicolumn{7}{|c|}{ Histology $(n=3,658)$} \\
\hline Ductal & 1 & & & 1 & & \\
\hline Lobular & 0.99 & $0.74-1.32$ & 0.94 & 1.01 & $0.73-1.40$ & 0.935 \\
\hline Other & 0.72 & $0.46-1.13$ & 0.15 & 0.87 & $0.55-1.39$ & 0.568 \\
\hline \multicolumn{7}{|c|}{ Grading $(n=3,641)$} \\
\hline G1 & 1 & & & 1 & & \\
\hline $\mathrm{G} 2$ & 3.05 & $2.05-4.55$ & 0.001 & 2.64 & $1.74-4.00$ & 0.001 \\
\hline G3 & 5.00 & $3.33-7.50$ & 0.001 & 4.04 & $2.63-6.19$ & 0.001 \\
\hline \multicolumn{7}{|c|}{ Lymphatic invasion $(n=3,382)$} \\
\hline L0 & 1 & & & 1 & & \\
\hline L1 & 2.55 & $2.07-3.14$ & 0.001 & 2.31 & $1.83-2.92$ & 0.001 \\
\hline \multicolumn{7}{|c|}{ Vascular invasion $(n=3,321)$} \\
\hline V0 & 1 & & & 1 & & \\
\hline V1 & 3.27 & $2.49-4.29$ & 0.001 & 2.72 & $1.98-3.75$ & 0.001 \\
\hline \multicolumn{7}{|c|}{ Estrogen receptor $(n=3,655)$} \\
\hline Positive & 1 & & & 1 & & \\
\hline Negative & 2.22 & $1.80-2.75$ & 0.001 & 2.23 & $1.76-2.82$ & 0.001 \\
\hline \multicolumn{7}{|c|}{ Progesterone receptor $(n=3,655)$} \\
\hline Positive & 1 & & & 1 & & \\
\hline Negative & 2.18 & $1.80-2.65$ & 0.001 & 2.14 & $1.72-2.66$ & 0.001 \\
\hline \multicolumn{7}{|c|}{ HER2/neu $(n=3,618)$} \\
\hline Negative & 1 & & & 1 & & \\
\hline Positive & 1.39 & $1.12-1.74$ & 0.003 & 1.23 & $0.96-1.59$ & 0.106 \\
\hline \multicolumn{7}{|c|}{ Receptor status $(n=3,655)$} \\
\hline $\mathrm{ER}+\mathrm{PR}+$ & 1 & & & 1 & & \\
\hline $\mathrm{ER}+\mathrm{PR}-$ & 1.86 & $1.40-2.47$ & 0.001 & 1.79 & $1.30-2.47$ & 0.001 \\
\hline $\mathrm{ER}-\mathrm{PR}+$ & 1.95 & $0.81-4.73$ & 0.138 & 2.01 & $0.75-5.40$ & 0.167 \\
\hline $\mathrm{ER}-\mathrm{PR}-$ & 2.45 & $1.96-3.07$ & 0.001 & 2.44 & $1.90-3.13$ & 0.001 \\
\hline
\end{tabular}




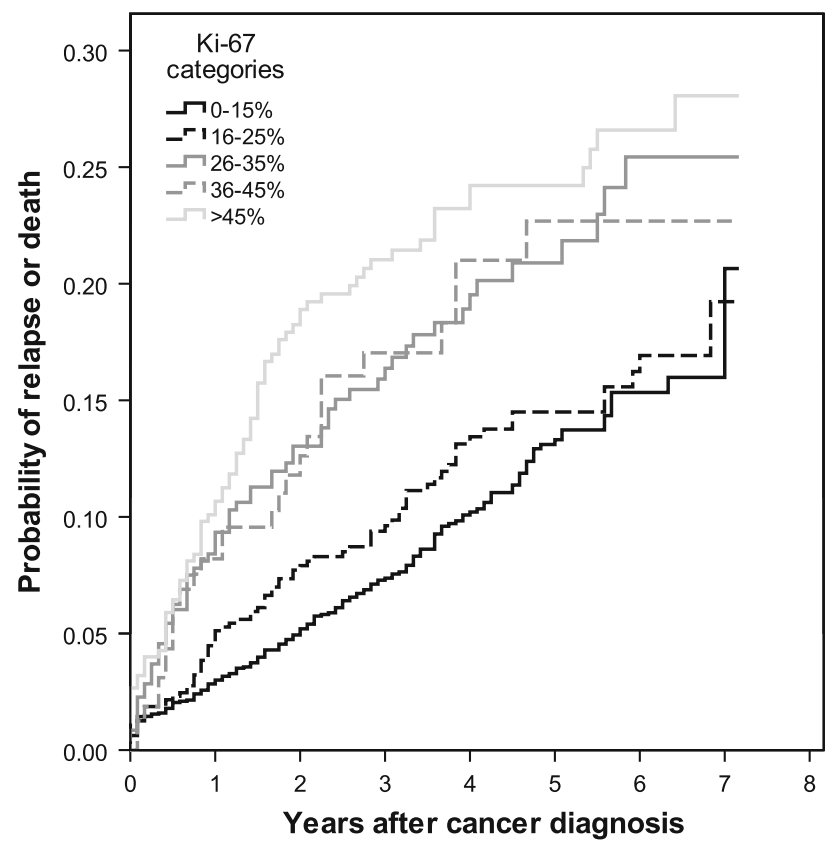

Fig. 3 Kaplan-Meier plot of disease-free survival in years based on Ki-67 categories

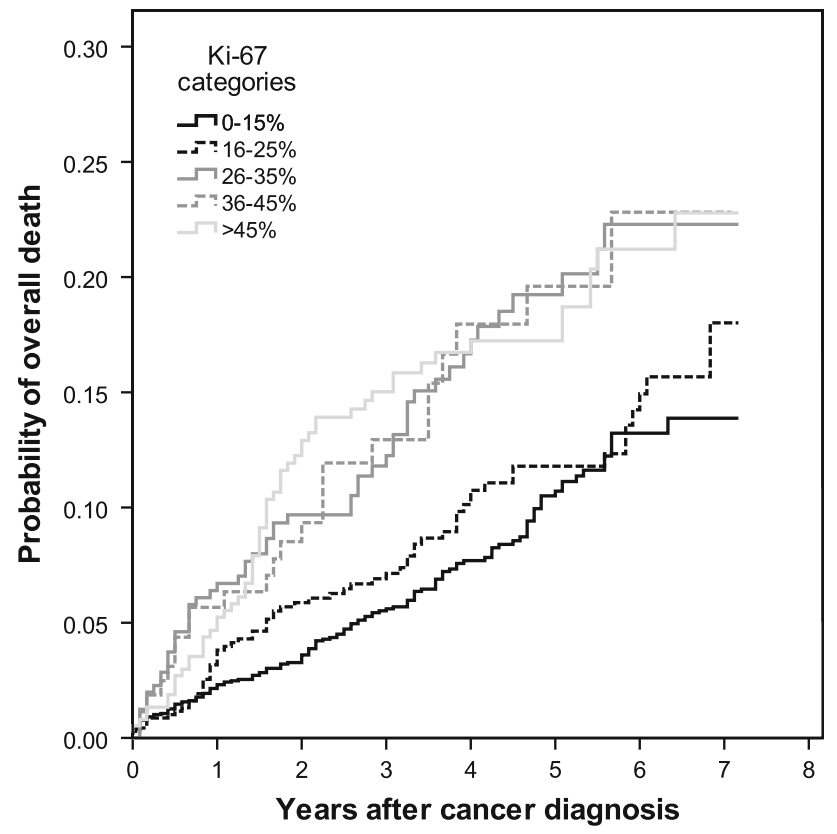

Fig. 4 Kaplan-Meier plot of overall survival in years based on Ki-67 categories

previously has been already considered as a biomarker for therapeutic decision [13, 50]. Colozza et al. [51] reviewed the role of proliferation markers as prognostic and predictive tools in early breast cancer. All of the chosen studies correlated statistically significant with DFS and OS in multivariate analysis. However, the selected studies enclosed, had a rather smaller number of patients ranging from 127 to 707 patients, and were limited to designated tumor stages. Two meta-analyses including studies performed between 2006 and 2011 elucidate the prognostic role of Ki-67 in breast cancer. It is notable that in both meta-analyses, the included studies applied different eligibility criteria, study design, methods for analyzing Ki-67, and cut-off points. The meta-analysis of de Azambuja et al. [17] investigated the prognostic value of $\mathrm{Ki}-67$ only in univariate analyses for both DFS and OS. Concerning DFS, data from 38 studies (including 10,954 patients) were comprised and a fixed effect HR of 1.88 (95\% CI 1.75-2.02) was found. In terms of OS, 35 studies were incorporated (including 9,472 patients) and a HR of 1.89 (1.74-2.06) was identified. In the meta-analysis by StuartHarris et al. [7], both univariate and multivariate analyses were reported. The pooled adjusted HRs were 2.05 (1.80-2.33) for DSF and $1.88(1.55-2.27)$ for OS in univariate analyses, and $1.76(1.56-1.98)$ for DFS and 1.42 (1.14-1.77) for OS in multivariate analyses. However, these data include merely data from clinical studies and study populations, but no data reflecting the routine medical care.

In this study, it was confirmed that $\mathrm{Ki}-67$ is as a prognostic factor in breast cancer patients in a routine setting. A 2010 published review article concluded increasing evidence that $\mathrm{Ki}-67$ is a valuable prognostic marker but as to its predictive role its applicability is limited [12]. No robust evidence was found that $\mathrm{Ki}-67$ can serve as a tool to identify patients who will benefit from a specific chemotherapy or endocrine treatment. Nevertheless, the validation of Ki-67 as a predictive factor was not the subject of the present study. This topic has been investigated in recent studies with inconsistent results. Contrary to the prognostic markers, predictive markers shall support in decision making of certain therapies as they appreciate the potential to respond to a therapy [52-54]. Various studies have explored the predictive value of Ki-67-labeling index of which some of them reported an association between high-pretreatment Ki-67-labeling index and better responses to chemotherapy in the neoadjuvant setting $[11,55-58]$ whereas other studies found no such association [47, 57, 59-61].

In conclusion, for the first time, a large cohort of a clinical cancer registry was analyzed assuring the data of clinical routine conditions. The current study demonstrated that Ki-67 is widely applied in routine clinical work. Ki-67 was associated with common histopathological parameters, but was shown to be an independent prognostic parameter for DFS and OS in breast cancer patients. These findings underline the importance of $\mathrm{Ki}-67$ as a prognostic parameter. Therefore, future work in this field is called for; it should focus on the standardization of Ki-67 assessment in routine clinical settings and on the role of $\mathrm{Ki}-67$ in treatment decisions. 
Table 4 Association of Ki-67 with clinical and histopathological parameters in multivariable analysis $(n=3,174$ due to occasional missing values)

\begin{tabular}{|c|c|c|c|c|c|c|}
\hline \multirow[t]{2}{*}{ Characteristic } & \multicolumn{3}{|c|}{ Disease-free survival } & \multicolumn{3}{|c|}{ Overall survival } \\
\hline & HR & $95 \% \mathrm{CI}$ & $P \leq$ & HR & $95 \% \mathrm{CI}$ & $P \leq$ \\
\hline Age & 1.05 & $1.04-1.07$ & 0.001 & 1.07 & $1.06-1.09$ & 0.001 \\
\hline \multicolumn{7}{|c|}{ Ki-67-categories $(\%)(n=3,174)$} \\
\hline$\leq 15$ & 1 & & & 1 & & \\
\hline $16-25$ & 1.00 & $0.72-1.39$ & 1.00 & 1.14 & $0.78-1.66$ & 0.49 \\
\hline $26-35$ & 1.44 & $0.97-2.12$ & 0.07 & 1.71 & $1.10-2.65$ & 0.017 \\
\hline $36-45$ & 1.50 & $0.91-2.48$ & 0.11 & 2.05 & $1.18-3.55$ & 0.011 \\
\hline$>45$ & 1.96 & $1.31-2.91$ & 0.001 & 2.06 & $1.30-3.28$ & 0.002 \\
\hline \multicolumn{7}{|l|}{ Menopausal status } \\
\hline Premenopausal & 1 & & & 1 & & \\
\hline Postmenopausal & 0.62 & $0.39-0.98$ & 0.041 & 0.62 & $0.35-1.10$ & 0.11 \\
\hline \multicolumn{7}{|l|}{ Tumor size } \\
\hline pT1 & 1 & & & 1 & & \\
\hline pT2 & 1.52 & $1.14-2.02$ & 0.003 & 1.52 & $1.09-2.12$ & 0.017 \\
\hline pT3 & 1.97 & $1.21-3.19$ & 0.008 & 2.03 & $1.16-3.56$ & 0.013 \\
\hline pT4 & 2.04 & $1.29-3.21$ & 0.003 & 2.24 & $1.36-3.70$ & 0.002 \\
\hline \multicolumn{7}{|l|}{ Nodal status } \\
\hline N0 & 1 & & & 1 & & \\
\hline N1 & 1.38 & $1.03-1.87$ & 0.034 & 1.31 & $0.93-1.86$ & 0.12 \\
\hline $\mathrm{N} 2$ & 1.88 & $1.29-2.74$ & 0.001 & 1.97 & $1.28-3.04$ & 0.002 \\
\hline N3 & 2.12 & $1.44-3.14$ & 0.001 & 2.28 & $1.46-3.57$ & 0.001 \\
\hline \multicolumn{7}{|l|}{ Histology } \\
\hline Ductal & 1 & & & 1 & & \\
\hline Lobular & 1.22 & $0.86-1.73$ & 0.26 & 1.23 & $0.82-1.84$ & 0.32 \\
\hline Other & 0.94 & $0.52-1.70$ & 0.83 & 1.05 & $0.56-1.97$ & 0.89 \\
\hline \multicolumn{7}{|l|}{ Grading } \\
\hline G1 & 1 & & & 1 & & \\
\hline $\mathrm{G} 2$ & 1.88 & $1.14-3.09$ & 0.013 & 1.62 & $0.95-2.80$ & 0.08 \\
\hline G3 & 1.96 & $1.12-3.41$ & 0.018 & 1.46 & $0.79-2.67$ & 0.23 \\
\hline \multicolumn{7}{|l|}{ Lymphatic invasion } \\
\hline L0 & 1 & & & 1 & & \\
\hline $\mathrm{L} 1$ & 1.20 & $0.91-1.59$ & 0.20 & 1.04 & $0.75-1.43$ & 0.82 \\
\hline \multicolumn{7}{|l|}{ Vascular invasion } \\
\hline V0 & 1 & & & 1 & & \\
\hline $\mathrm{V} 1$ & 1.44 & $1.04-2.01$ & 0.030 & 1.28 & $0.87-1.89$ & 0.21 \\
\hline \multicolumn{7}{|l|}{ Estrogen receptor } \\
\hline Positive & 1 & & & 1 & & \\
\hline Negative & 1.41 & $0.97-2.06$ & 0.073 & 1.85 & $1.19-2.89$ & 0.007 \\
\hline \multicolumn{7}{|c|}{ Progesterone receptor } \\
\hline Positive & 1 & & & 1 & & \\
\hline Negative & 1.39 & $0.99-1.95$ & 0.056 & 1.29 & $0.87-1.93$ & 0.21 \\
\hline \multicolumn{7}{|l|}{ HER2/neu } \\
\hline Negative & 1 & & & 1 & & \\
\hline Positive & 0.86 & $0.65-1.14$ & 0.28 & 0.70 & $0.80-0.98$ & 0.036 \\
\hline
\end{tabular}


Table 5 Three- and five-year disease-free survival and overall survival rates categorized by $\mathrm{Ki}-67$

\begin{tabular}{|c|c|c|c|c|}
\hline \multirow[t]{2}{*}{ Ki-67 categories $(\%)$} & \multicolumn{2}{|c|}{ DFS rate } & \multicolumn{2}{|l|}{ OS rate } \\
\hline & $\begin{array}{l}3 \text { years } \\
(\%)\end{array}$ & $\begin{array}{l}5 \text { years } \\
(\%)\end{array}$ & $\begin{array}{l}3 \text { years } \\
(\%)\end{array}$ & $\begin{array}{l}5 \text { years } \\
(\%)\end{array}$ \\
\hline $0-15$ & 92.6 & 86.7 & 94.4 & 89.3 \\
\hline $16-25$ & 90.4 & 83.1 & 92.9 & 88.2 \\
\hline $26-35$ & 83.6 & 79.1 & 87.7 & 80.8 \\
\hline $36-45$ & 83.0 & 77.3 & 87.1 & 80.4 \\
\hline$>45$ & 79.0 & 75.8 & 85.0 & 82.8 \\
\hline
\end{tabular}

Conflict of interest The authors declare that they have no conflict of interest.

Open Access This article is distributed under the terms of the Creative Commons Attribution Noncommercial License which permits any noncommercial use, distribution, and reproduction in any medium, provided the original author(s) and the source are credited.

\section{References}

1. Goldhirsch A, Wood WC, Coates AS, Gelber RD, Thurlimann B, Senn HJ (2011) Strategies for subtypes-dealing with the diversity of breast cancer: highlights of the St. Gallen International Expert Consensus on the Primary Therapy of Early Breast Cancer 2011. Ann Oncol 22:1736-1747

2. Hanahan D, Weinberg RA (2000) The hallmarks of cancer. Cell 100:57-70

3. Milde-Langosch K, Karn T, Müller V, Witzel I, Rody A, Schmidt M, Wirtz RM (2013) Validity of the proliferation markers Ki67, TOP2A, and RacGAP1 in molecular subgroups of breast cancer. Breast Cancer Res Treat 137(1):57-67. doi:10.1007/s10549-0122296-x

4. Wirapati P, Sotiriou C, Kunkel S, Farmer P, Pradervand S, HaibeKains B, Desmedt C, Ignatiadis M, Sengstag T, Schutz F et al (2008) Meta-analysis of gene expression profiles in breast cancer: toward a unified understanding of breast cancer subtyping and prognosis signatures. Breast Cancer Res 10:R65

5. Garcia RL, Coltrera MD, Gown AM (1989) Analysis of proliferative grade using anti-PCNA/cyclin monoclonal antibodies in fixed, embedded tissues. Comparison with flow cytometric analysis. Am J Pathol 134(4):733-739

6. Ignatiadis M, Sotiriou C (2008) Understanding the molecular basis of histologic grade. Pathobiology 75(2):104-111. doi:10.1159/ 000123848

7. Stuart-Harris R, Caldas C, Pinder SE, Pharoah P (2008) Proliferation markers and survival in early breast cancer: a systematic review and meta-analysis of 85 studies in 32,825 patients. Breast 17:323-334

8. Gerdes J, Schwab U, Lemke H, Stein H (1983) Production of a mouse monoclonal antibody reactive with a human nuclear antigen associated with cell proliferation. Int $\mathrm{J}$ Cancer 31(1): $13-20$

9. Gerdes J, Lemke H, Baisch H, Wacker HH, Schwab U, Stein H (1984) Cell cycle analysis of a cell proliferation-associated human nuclear antigen defined by the monoclonal antibody Ki67. J Immunol 133(4):1710-1715

10. Scholzen T, Gerdes J (2000) The Ki-67 protein: from the known and the unknown. J Cell Physiol 182(3):311-322
11. Urruticoechea A, Smith IE, Dowsett M (2005) Proliferation marker Ki-67 in early breast cancer. J Clin Oncol 23:7212-7220

12. Yerushalmi R, Woods R, Ravdin PM, Hayes MM, Gelmon KA (2010) Ki67 in breast cancer: prognostic and predictive potential. Lancet Oncol 11:174-183

13. Luporsi E, André F, Spyratos F, Martin PM, Jacquemier J, Penault-Llorca F, Tubiana-Mathieu N, Sigal-Zafrani B, Arnould L, Gompel A et al (2012) Ki-67: level of evidence and methodological considerations for its role in the clinical management of breast cancer: analytical and critical review. Breast Cancer Res Treat 132(3):895-915. doi:10.1007/s10549-011-1837-z

14. Gnant M, Harbeck N, Thomssen C (2011) St. Gallen Summary of the Consensus Discussion. Breast Care (Basel) 6(2):136-141

15. Untch M, Gerber B, Möbus V, Schneeweiss A, Thomssen C, von Minckwitz G, Beckmann MW, Blohmer JU, Costa SD, Diedrich K et al (2011) Zurich Consensus: Statement of German Experts on St. Gallen Conference 2011 on Primary Breast Cancer (Zurich 2011). Breast Care 6:144-152. doi:10.1159/000327999

16. Untch M, Gerber B, Harbeck N, Jackisch C, Marschner N, Möbus V, von Minckwitz G, Loibl S (2013) $13^{\text {th }}$ St. Gallen International Breast Cancer Conference 2013: Primary Therapy of Early Breast Cancer Evidence, Controversies, Consensus. Breast Care 03/2013: in press

17. de Azambuja E, Cardoso F, de Castro G, Colozza M Jr, Mano MS, Durbecq V, Sotiriou C, Larsimont D, Piccart-Gebhart MJ, Paesmans M (2007) Ki-67 as prognostic marker in early breast cancer: a meta-analysis of published studies involving 12,155 patients. Br J Cancer 96(10):1504-1513

18. Harris L, Fritsche H, Mennel R, Norton L, Ravdin P, Taube S, Somerfield MR, Hayes DF, Bast RC Jr (2007) American Society of Clinical Oncology 2007 update of recommendations for the use of tumor markers in breast cancer. J Clin Oncol 25(33): $5287-5312$

19. Dowsett M, Nielsen TO, A'Hern R, Bartlett J, Coombes RC, Cuzick J, Ellis M, Henry NL, Hugh JC, Lively T et al (2011) Assessment of Ki67 in breast cancer: recommendations from the International Ki67 in Breast Cancer Working Group. J Natl Cancer Inst 103:1656-1664

20. Perou CM, Sorlie T, Eisen MB, van de Rijn M, Jeffrey SS, Rees CA, Pollack JR, Ross DT, Johnsen H, Akslen LA et al (2000) Molecular portraits of human breast tumours. Nature 406: $747-752$

21. Sparano JA, Paik S (2008) Development of the 21-gene assay and its application in clinical practice and clinical trials. J Clin Oncol 26(5):721-728. doi:10.1200/JCO.2007.15.1068

22. Paik S, Shak S, Tang G, Kim C, Baker J, Cronin M, Baehner FL, Walker MG, Watson D, Park T et al (2004) A multigene assay to predict recurrence of tamoxifen-treated, node-negative breast cancer. N Engl J Med 351(27):2817-2826

23. Cardoso F, Van't Veer L, Rutgers E, Loi S, Mook S, PiccartGebhart MJ (2008) Clinical application of the 70-gene profile: the MINDACT trial. J Clin Oncol 26(5):729-735. doi:10.1200/ JCO.2007.14.3222

24. van de Vijver MJ, He YD, van't Veer LJ, Dai H, Hart AA, Voskuil DW, Schreiber GJ, Peterse JL, Roberts C, Marton MJ et al (2002) A gene-expression signature as a predictor of survival in breast cancer. N Engl J Med 347(25):1999-2009

25. Oakman C, Bessi S, Zafarana E, Galardi F, Biganzoli L, Di Leo A (2009) Recent advances in systemic therapy: new diagnostics and biological predictors of outcome in early breast cancer. Breast Cancer Res 11(2):205. doi:10.1186/bcr2238

26. Cuzick J, Dowsett M, Pineda S, Wale C, Salter J, Quinn E, Zabaglo L, Mallon E, Green AR, Ellis IO et al (2011) Prognostic value of a combined estrogen receptor, progesterone receptor, $\mathrm{Ki}$ 67 , and human epidermal growth factor receptor 2 immunohistochemical score and comparison with the Genomic Health 
recurrence score in early breast cancer. J Clin Oncol 29(32): 4273-4278. doi:10.1200/JCO.2010.31.2835

27. Schmidt M, Fasching PA, Beckmann MW, Kölbl H (2012) Biomarkers in Breast Cancer: An Update. Geburtsh Frauenheilk 72(9):819-832. doi:10.1055/s-0032-1315340

28. Elston CW, Ellis IO (1991) Pathological prognostic factors in breast cancer. I. The value of histological grade in breast cancer: experience from a large study with long-term follow-up. Histopathology 19:403-410

29. Elston CW, Ellis IO (1993) Method for grading breast cancer. J Clin Pathol 46(2):189-190

30. Sahin AA, Ro J, Ro JY, Blick MB, el-Naggar AK, Ordonez NG, Fritsche HA, Smith TL, Hortobagyi GN, Ayala AG (1991) Ki-67 immunostaining in node-negative stage I/II breast carcinoma. Significant correlation with prognosis. Cancer 68(3):549-557

31. Rudas M, Gnant MF, Mittlböck M, Neumayer R, Kummer A, Jakesz R, Reiner G, Reiner A (1994) Thymidine labeling index and Ki-67 growth fraction in breast cancer: comparison and correlation with prognosis. Breast Cancer Res Treat 32(2): 165-175

32. Pinder SE, Wencyk P, Sibbering DM, Bell JA, Elston CW, Nicholson R, Robertson JF, Blamey RW, Ellis IO (1995) Assessment of the new proliferation marker MIB1 in breast carcinoma using image analysis: associations with other prognostic factors and survival. Br J Cancer 71(1):146-149

33. Pierga JY, Leroyer A, Viehl P, Mosseri V, Chevillard S, Magdelénat $H$ (1996) Long term prognostic value of growth fraction determination by Ki-67 immunostaining in primary operable breast cancer. Breast Cancer Res Treat 37(1):57-64

34. Liu S, Edgerton SM, Moore DH 2nd, Thor AD (2001) Measures of cell turnover (proliferation and apoptosis) and their association with survival in breast cancer. Clin Cancer Res 7(6):1716-1723

35. Spyratos F, Ferrero-Poüs M, Trassard M, Hacène K, Phillips E, Tubiana-Hulin M, Le Doussal V (2002) Correlation between MIB-1 and other proliferation markers: clinical implications of the MIB-1 cutoff value. Cancer 94(8):2151-2159

36. Trihia H, Murray S, Price K, Gelber RD, Golouh R, Goldhirsch A, Coates AS, Collins J, Castiglione-Gertsch M, Gusterson BA; International Breast Cancer Study Group (2003) Ki-67 expression in breast carcinoma: its association with grading systems, clinical parameters, and other prognostic factors-a surrogate marker? Cancer 97(5):1321-1331

37. Brown RW, Allred CD, Clark GM, Osborne CK, Hilsenbeck SG (1996) Prognostic value of Ki-67 compared to S-phase fraction in axillary node-negative breast cancer. Clin Cancer Res 2(3):585-592

38. Haerslev T, Jacobsen GK, Zedeler K (1996) Correlation of growth fraction by Ki-67 and proliferating cell nuclear antigen (PCNA) immunohistochemistry with histopathological parameters and prognosis in primary breast carcinomas. Breast Cancer Res Treat 37(2):101-113

39. Molino A, Micciolo R, Turazza M, Bonetti F, Piubello Q, Bonetti A, Nortilli R, Pelosi G, Cetto GL (1997) Ki-67 immunostaining in 322 primary breast cancers: associations with clinical and pathological variables and prognosis. Int J Cancer 74(4):433-437

40. Kontzoglou K, Palla V, Karaolanis G, Karaiskos I, Alexiou I, Pateras I, Konstantoudakis K, Stamatakos M (2013) Correlation between Ki67 and Breast Cancer Prognosis. Oncology 84(4):219-225. doi:10.1159/000346475

41. Aleskandarany MA, Green AR, Benhasouna AA, Barros FF, Neal K, Reis-Filho JS, Ellis IO, Rakha EA (2012) Prognostic value of proliferation assay in the luminal, HER2-positive, and triplenegative biologic classes of breast cancer. Breast Cancer Res 14(1):R3

42. Viale G, Giobbie-Hurder A, Regan MM, Coates AS, Mastropasqua MG, Dell'Orto P, Maiorano E, MacGrogan G, Braye SG,
Ohlschlegel C et al (2008) Prognostic and predictive value of centrally reviewed Ki-67 labeling index in postmenopausal women with endocrine-responsive breast cancer: results from Breast International Group Trial 1-98 comparing adjuvant tamoxifen with letrozole. J Clin Oncol 26(34):5569-5575. doi:10.1200/JCO.2008.17.0829

43. Jacquemier J, Charafe-Jauffret E, Monville F, Esterni B, Extra JM, Houvenaeghel G, Xerri L, Bertucci F, Birnbaum D (2009) Association of GATA3, P53, Ki67 status and vascular peritumoral invasion are strongly prognostic in luminal breast cancer. Breast Cancer Res 11(2):R23. doi:10.1186/bcr2249

44. Wiesner FG, Magener A, Fasching PA, Wesse J, Bani MR, Rauh C, Jud S, Schrauder M, Loehberg CR, Beckmann MW et al (2009) Ki-67 as a prognostic molecular marker in routine clinical use in breast cancer patients. Breast 18(2):135-141. doi:10.1016/ j.breast.2009.02.009

45. Domagala W, Markiewski M, Harezga B, Dukowicz A, Osborn M (1996) Prognostic significance of tumor cell proliferation rate as determined by the MIB-1 antibody in breast carcinoma: its relationship with vimentin and p53 protein. Clin Cancer Res 2(1):147-154

46. Jansen RL, Hupperets PS, Arends JW, Joosten-Achjanie SR, Volovics A, Schouten HC, Hillen HF (1998) MIB-1 labelling index is an independent prognostic marker in primary breast cancer. Br J Cancer 78(4):460-465

47. Viale G, Regan MM, Mastropasqua MG, Maffini F, Maiorano E, Colleoni M, Price KN, Golouh R, Perin T, Brown RW et al (2008) Predictive value of tumor Ki-67 expression in two randomized trials of adjuvant chemoendocrine therapy for nodenegative breast cancer. J Natl Cancer Inst 100(3):207-212. doi:10.1093/jnci/djm289

48. Cheang MC, Chia SK, Voduc D, Gao D, Leung S, Snider J, Watson M, Davies S, Bernard PS, Parker JS et al (2009) Ki67 index, HER2 status, and prognosis of patients with luminal B breast cancer. J Natl Cancer Inst 101(10):736-750. doi:10.1093/ jnci/djp082

49. Kashiwagi S, Yashiro M, Takashima T, Aomatsu N, Ikeda K, Ogawa Y, Ishikawa T, Hirakawa K (2011) Advantages of adjuvant chemotherapy for patients with triple-negative breast cancer at Stage II: usefulness of prognostic markers E-cadherin and Ki67. Breast Cancer Res 13(6):R122. doi:10.1186/bcr3068

50. Loehberg CR, Almstedt K, Jud SM, Haeberle L, Fasching PA, Hack CC, Lux MP, Thiel FC, Schrauder MG, Brunner M et al (2013) Prognostic relevance of Ki-67 in the primary tumor for survival after a diagnosis of distant metastasis. Breast Cancer Res Treat 138(3):899-908. doi:10.1007/s10549-013-2460-y

51. Colozza M, Azambuja E, Cardoso F, Sotiriou C, Larsimont D, Piccart MJ (2005) Proliferative markers as prognostic and predictive tools in early breast cancer: where are we now? Ann Oncol 16:1723-1739

52. Harbeck N, Salem M, Nitz U, Gluz O, Liedtke C (2010) Personalized treatment of early-stage breast cancer: present concepts and future directions. Cancer Treat Rev 36(8):584-594. doi:10.1016/j.ctrv.2010.04.007

53. Lüftner D, Lux MP, Maass N, Schütz F, Schwidde I, Fasching PA, Fehm T, Janni W, Kümmel S, Kolberg HC (2012) Advances in Breast Cancer: Looking Back over the year. Geburtsh Frauenheilk 72(12):1117-1129. doi:10.1055/s-0032-1328084

54. Kolberg HC, Lüftner D, Lux MP, Maass N, Schütz F, Fasching PA, Fehm T, Janni W, Kümmel S (2012) Breast Cancer 2012: new aspects. Geburtsh Frauenheilk 72(7):602-615. doi:10.1055/ s-0032-1315131

55. Chang J, Ormerod M, Powles TJ, Allred DC, Ashley SE, Dowsett M (2000) Apoptosis and proliferation as predictors of chemotherapy response in patients with breast carcinoma. Cancer 89(11):2145-2152 
56. Archer CD, Parton M, Smith IE, Ellis PA, Salter J, Ashley S, Gui G, Sacks N, Ebbs SR, Allum W, Nasiri N, Dowsett M (2003) Early changes in apoptosis and proliferation following primary chemotherapy for breast cancer. Br J Cancer 89(6):1035-1041

57. Assersohn L, Salter J, Powles TJ, A'hern R, Makris A, Gregory RK, Chang J, Dowsett M (2003) Studies of the potential utility of Ki67 as a predictive molecular marker of clinical response in primary breast cancer. Breast Cancer Res Treat 82(2):113-123

58. Keam B, Im SA, Lee KH, Han SW, Oh DY, Kim JH, Lee SH, Han W, Kim DW, Kim TY et al (2011) Ki-67 can be used for further classification of triple negative breast cancer into two subtypes with different response and prognosis. Breast Cancer Res 13(2):R22. doi:10.1186/bcr2834

59. Bottini A, Berruti A, Bersiga A, Brizzi MP, Bruzzi P, Aguggini S, Brunelli A, Bolsi G, Allevi G, Generali D et al (2001)
Relationship between tumour shrinkage and reduction in Ki67 expression after primary chemotherapy in human breast cancer. Br J Cancer 85(8):1106-1112

60. Colleoni M, Zahrieh D, Gelber RD, Viale G, Luini A, Veronesi P, Intra M, Galimberti V, Renne G, Goldhirsch A (2003) Preoperative systemic treatment: prediction of responsiveness. Breast 12(6):538-542

61. Ferguson NL, Bell J, Heidel R, Lee S, Vanmeter S, Duncan L, Munsey B, Panella T, Orucevic A (2013) Prognostic value of breast cancer subtypes, Ki-67 proliferation index, age, and pathologic tumor characteristics on breast cancer survival in Caucasian women. Breast J 19(1):22-30. doi:10.1111/tbj.12059 